\title{
EFFICIENCY OF AQUATIC MACROPHYTES TO TREAT NILE TILAPIA POND EFFLUENTS
}

\author{
Gustavo Gonzaga Henry-Silva ${ }^{1}$; Antonio Fernando Monteiro Camargo ${ }^{2 *}$ \\ ${ }^{1}$ UFERSA - Depto. de Engenharia de Pesca, BR 110, km 47 - 59625-900 - Mossoró, RN - Brasil. \\ ${ }^{2}$ UNESP/CAUNESP - Depto. de Ecologia, C.P. 199 - 13506-900 - Rio Claro, SP - Brasil. \\ *Corresponding author <afmc@rc.unesp.br>
}

\begin{abstract}
The effluents from fish farming can increase the quantity of suspended solids and promote the enrichment of nitrogen and phosphorus in aquatic ecosystems. In this context, the aim of this work was to evaluate the efficiency of three species of floating aquatic macrophytes (Eichhornia crassipes, Pistia stratiotes and Salvinia molesta) to treat effluents from Nile tilapia culture ponds. The effluent originated from a 1,000- $\mathrm{m}^{2}$ pond stocked with 2,000 male Nile tilapia Oreochromis niloticus. The treatment systems consisted of 12 experimental tanks, three tanks for each macrophyte species, and three control tanks (without plants). Water samples were collected from the: (i) fish pond source water, (ii) effluent from fish pond and (iii) effluents from the treatment tanks. The following water variables were evaluated: turbidity, total and dissolved nitrogen, ammoniacal-N, nitrate-N, nitrite-N, total phosphorus and dissolved phosphorus. E. crassipes and P. stratiotes were more efficient in total phosphorus removal $(82.0 \%$ and $83.3 \%$, respectively) and total nitrogen removal (46.1\% and $43.9 \%$, respectively) than the $S$. molesta ( $72.1 \%$ total phosphorus and $42.7 \%$ total nitrogen) and the control $(50.3 \%$ total phosphorus and $22.8 \%$ total nitrogen), indicating that the treated effluents may be reused in the aquaculture activity.
\end{abstract}

Key words: Eichhornia crassipes, Pistia stratiotes, Salvinia molesta, aquaculture, nutrients

\section{EFICIÊNCIADE MACRÓFITAS AQUÁTICAS NO TRATAMENTO DE EFLUENTES DE VIVEIRO DE TILÁPIA DO NILO}

\begin{abstract}
RESUMO: Os efluentes de piscicultura podem aumentar a quantidade de sólidos em suspensão e promover o enriquecimento de nitrogênio e fósforo nos ecossistemas aquáticos. Neste contexto, o objetivo deste trabalho foi avaliar a eficiência de três espécies de macrófitas aquáticas flutuantes (Eichhornia crassipes, Pistia stratiotes e Salvinia molesta) no tratamento de efluentes do viveiro de tilápia do Nilo. O efluente foi proveniente de um viveiro com $1000 \mathrm{~m}^{2}$ contendo 2000 machos de tilápia do Nilo (Oreochromis niloticus). Os sistemas de tratamento consistiram de 12 taques experimentais, três tanques para cada espécie de macrófita estudada, e três tanques sem plantas (controle). Amostras foram coletadas da água de abastecimento do tanque de tilápia do Nilo (i); do efluente do viveiro com tilápia do Nilo (ii) e dos efluentes tratados pelas macrófitas aquáticas (iii). As seguintes variáveis foram determinadas: turbidez, nitrogênio total, nitrogênio dissolvido, N-amoniacal, N-nitrato, N-nitrito, e fósforo total e fósforo dissolvido. E. crassipes e P. stratiotes foram mais eficientes na remoção de fósforo total $(82,0 \%$ e $83,3 \%$, respectivamente) e nitrogênio total $(46,1 \%$ e $43,9 \%$, respectivamente) do que quando comparadas com $S$. molesta $(72,1 \%$ de fósforo total e $42,7 \%$ de nitrogênio total) e com o controle $(50,3 \%$ de fósforo total e $22,8 \%$ de nitrogênio total). Pode-se concluir que as macrófitas aquáticas, principalmente E. crassipes e $P$. stratiotes foram eficientes na remoção de nitrogênio e fósforo dos efluentes de criação de tilápia do Nilo. Desta forma, o efluente tratado pode ser utilizado nas próprias atividades de aqüicultura.

Palavras-chave: Eichhornia crassipes, Pistia stratiotes, Salvinia molesta, aqüicultura, nutrientes
\end{abstract}

\section{INTRODUCTION}

The main input of energy in intensive aquaculture is fish feed, partly transformed into fish biomass and partly released into the water as suspended organic solids, carbon dioxide, ammonia, phosphates and other compounds (Boyd, 2003; True, et al., 2004; Baccarin \& Camargo, 2005). Together with excretory products, this can result in a considerable input of organic and inorganic matter to the aquatic ecosystem (Piedrahita, 2003; Stephens \& Farris, 2004). To reduce this effluent loading it is important to formulate highly digestible diets with lower nutrient levels. In addition, it is necessary to treat effluents to attend new legislative demands and the pressure coming from environmentalists. 
Treating effluents using aquatic macrophytes may be an alternative approach for fish farming management. Macrophyte-based wastewater treatment systems are relatively inexpensive to construct and operate, easy to maintain and provide effective and reliable wastewater treatments (Farahbakhshazad et al., 2000; Lin et al., 2005; Greenway, 2005; Hadad et al., 2006). The resulting gains in vegetative biomass can also provide economic returns when harvested (El-Sayed, 1999; Singhal \& Rai, 2003). Some floating aquatic macrophytes are used in constructed wetlands, mainly in tropical countries, due to their capacity to absorb and store large quantities of nutrients, and their rapid growth rate (Ran et al., 2004; Costa-Pierce, 1998). In Brazil, floating aquatic macrophyte species are abundant and widely distributed, occurring both in polluted and non-polluted aquatic ecosystems (Thomaz \& Bini, 1998; Henry-Silva \& Camargo, 2003; 2005).

The aim of this study was to evaluate the efficiency of the floating aquatic macrophytes Eichhornia crassipes, Pistia stratiotes and Salvinia molesta to treat wastewater from Nile tilapia (Oreochromis niloticus) culture ponds.

\section{MATERIAL AND METHODS}

\section{Experimental Design}

The research was carried out in Pirassununga, SP, Brazil ( $21^{\circ} 55^{\prime} 46^{\prime \prime}$ S and 47 $22^{\prime} 24^{\prime \prime}$ 'W) between December (1999) and May (2000), during the hot season, in a completely randomized design with four treatments (Eichhornia crassipes, Pistia stratiotes, Salvinia molesta and control) $(\mathrm{n}=3)$ (Figure 1). These macrophytes were placed in 2,000 L outdoor concrete tanks $\left(4.0 \mathrm{~m}^{2}\right.$ surface area) in triplicate, with continuous wa-

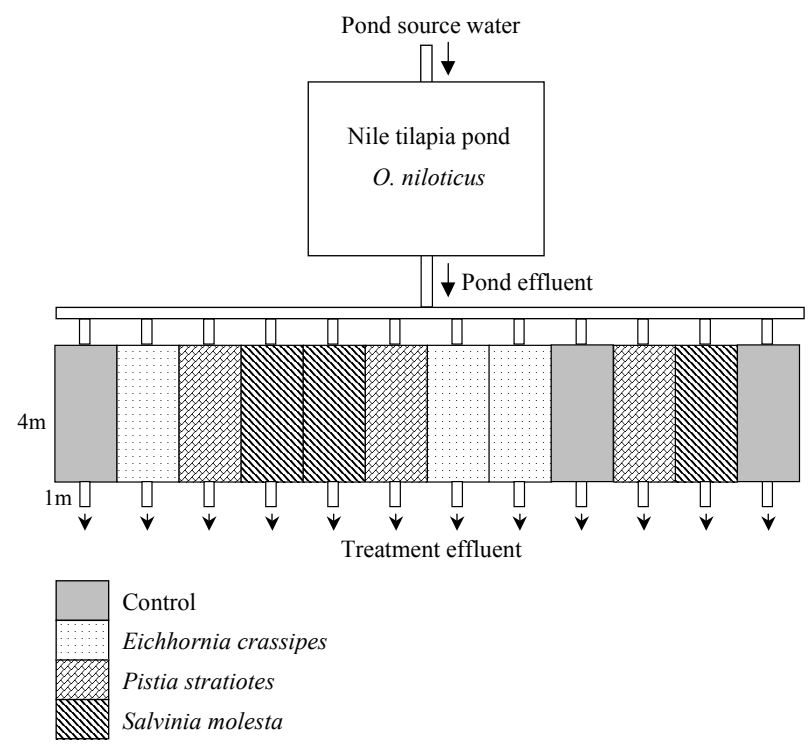

Figure 1 - Schematic diagram of the aquatic macrophyte systems. ter flow, used for each plant type. Three tanks without plants served as control. The water turnover rate of each experimental tank was 33 hours. Vegetative biomass of each species covered approximately $80 \%$ of water surfaces. Initial standing crops in the tanks were: E. crassipes $5.50 \mathrm{~kg}$ wet weight $\mathrm{m}^{-2} ;$ P. stratiotes $3.70 \mathrm{~kg}$ wet weight $\mathrm{m}^{-2}$; and $S$. molesta $3.37 \mathrm{~kg}$ wet weight $\mathrm{m}^{-2}$. Plant material was collected biweekly from $0.25 \mathrm{~m}^{2}$ floating frames for measurement wet weight and returned to the tanks.

\section{The Nile Tilapia Pond}

Juvenile males of Nile tilapia (24 g) were stocked in a $1,000 \mathrm{~m}^{2}\left(2\right.$ fish $\left.\mathrm{m}^{-2}\right)$ pond in order to generate the waste to be treated by the experimental systems with aquatic macrophyte species. Fish were hand fed daily (ad libitum) at $10 \mathrm{~h} 00 \mathrm{~m}$ and $16 \mathrm{~h} 00 \mathrm{~m}$ using a commercial tilapia diet. At the end of the experiment, Nile tilapia had mean individual weight gain of $266 \mathrm{~g}$. Feed conversion rate was $0.77 \%$ per day and the total amount of ration supplied was $450 \mathrm{~kg}$.

\section{Weekly Monitoring - Water Quality}

Weekly samples were collected from: (i) pond source water, (ii) pond effluent and (iii) treatments effluents (Figure 1). Sampling was carried out between 08:30 a.m. and 09:30 a.m. hours for fourteen weeks. Turbidity was monitored using a Horiba U-10 multisensor, in NTU units (Nepholometric Turbidity Units). Total and dissolved nitrogen (total-N and dissolved-N), nitrite- $\mathrm{N}$ and nitrate- $\mathrm{N}$ concentrations were determined according to Mackereth et al. (1978) and ammoniacal-N by the method proposed by Koroleff (1976). Total phosphorus (total-P) and dissolved phosphorus (dissolved-P) concentrations were determined according to Golterman et al. (1978).

\section{Statistical Analyses}

The dry mass (DM) of aquatic macrophytes was estimated by a simple linear regression equation between wet and dry weight (Zar, 1999). Mean (14 weeks) removal percentage of nutrients and turbidity by treatment systems was calculated by:

$$
\mathrm{R}=100-\left[\left(100 * \mathrm{NC}_{\mathrm{te}}\right) / \mathrm{NC}_{\mathrm{pe}}\right]
$$

where: $\mathrm{R}=$ removal percentage, $\mathrm{NC}_{\mathrm{te}}=$ nutrient concentration of the treatment effluent and $\mathrm{NC}_{\mathrm{pe}}=$ nutrient concentration of the pond effluent.

\section{RESULTS}

\section{Pond source water and pond effluent}

Nitrogen, phosphorus and turbidity increased in pond effluent as compared with pond source water 
Table 1 - Means \pm standard deviations (14 weeks) for turbidity, nitrogen and phosphorus of pond source water, pond effluent and treatments systems (control, Salvinia molesta, Eichhornia crassipes and Pistia stratiotes).

\begin{tabular}{lcccccc}
\hline Variable & $\begin{array}{c}\text { Pond Source } \\
\text { Water }\end{array}$ & Pond Effluent & Control & E. crassipes & P. stratiotes & S. molesta \\
& $10.0 \pm 4.0$ & $26.0 \pm 12.0$ & $12.0 \pm 4.0$ & $2.0 \pm 2.0$ & $3.0 \pm 1.0$ & $4.0 \pm 2.0$ \\
\hline Turbidity $(\mathrm{NTU})$ & $0.20 \pm 0.03$ & $0.34 \pm 0.06$ & $0.27 \pm 0.06$ & $0.19 \pm 0.04$ & $0.19 \pm 0.05$ & $0.20 \pm 0.05$ \\
Total-N $\left(\mathrm{mg} \mathrm{L}^{-1}\right)$ & $0.16 \pm 0.03$ & $0.25 \pm 0.05$ & $0.20 \pm 0.04$ & $0.15 \pm 0.03$ & $0.15 \pm 0.03$ & $0.16 \pm 0.03$ \\
Dissolved-N $\left(\mathrm{mg} \mathrm{L}^{-1}\right)$ & $22.1 \pm 10.4$ & $74.9 \pm 18.4$ & $37.2 \pm 14.7$ & $13.5 \pm 5.2$ & $12.5 \pm 5.6$ & $20.9 \pm 7.9$ \\
Total-P $\left(\mu \mathrm{g} \mathrm{L}^{-1}\right)$ & $11.6 \pm 4.1$ & $28.1 \pm 8.4$ & $18.5 \pm 6.9$ & $7.9 \pm 5.5$ & $7.1 \pm 3.7$ & $12.4 \pm 6.3$ \\
Dissolved-P $\left(\mu \mathrm{g} \mathrm{L}^{-1}\right)$ & $4.20 \pm 1.9$ & $10.3 \pm 4.7$ & $6.1 \pm 2.9$ & $3.1 \pm 1.8$ & $3.6 \pm 2.3$ & $4.0 \pm 1.8$ \\
Amoniacal-N $\left(\mu \mathrm{g} \mathrm{L}^{-1}\right)$ & $6.7 \pm 1.8$ & $9.1 \pm 2.3$ & $7.5 \pm 2.0$ & $6.1 \pm 2.2$ & $6.3 \pm 1.8$ & $6.9 \pm 2.1$ \\
Nitrite-N $\left(\mu \mathrm{g} \mathrm{L}^{-1}\right)$ & $44.0 \pm 29.7$ & $48.7 \pm 22.8$ & $35.3 \pm 16.1$ & $21.8 \pm 10.1$ & $25.1 \pm 11.6$ & $48.4 \pm 21.5$ \\
\hline Nitrate-N $\left(\mu \mathrm{g} \mathrm{L}^{-1}\right)$ & & & &
\end{tabular}

NTU $=$ Nepholometric Turbidity Units

(Table 1). For pond effluent, the mean concentration of phosphorus, nitrogen and turbidity increased during the experiment. During the first week, concentrations of total-P and dissolved-P were 45.5 and 17.6 $\mu \mathrm{g} \mathrm{L} \mathrm{L}^{-1}$, respectively, and at the end of the experimental period the concentrations were 106.5 and $32.1 \mu \mathrm{g}$ $\mathrm{L}^{-1}$, respectively. Mean values of turbidity varied from 12 to 53 NTU (Figure 2).

\section{Effluents treated with aquatic macrophytes}

Pond effluent quality improved after treatment with E. crassipes, P. stratiotes and S. molesta (Table 1). Concentrations of total-P, dissolved-P, total-N and dissolved-N, and the turbidity of the effluents treated by the tree species of aquatic macrophytes were lower when compared to the values of the pond effluent for all weeks. The lowest values of such variables were observed for effluents treated with E. crassipes and P. stratiotes (Figure 2).

The highest mean removal percentage (which was achieved along 14 weeks) of phosphorus, nitrogen and turbidity were obtained by E. crassipes (82.0\% total-P; $71.8 \%$ dissolved-P; $46.1 \%$ total-N; $39.1 \%$ dissolved-N; 70.2\% $\mathrm{NH}_{3}-\mathrm{N} ; 36.2 \% \mathrm{NO}_{2}-\mathrm{N}$; $55.6 \% \mathrm{NO}_{3}-\mathrm{N} ; 90.6 \%$ turbidity) and $P$. stratiotes (83.3\% total-P; $74.9 \%$ dissolved-P; $43.9 \%$ total-N; $36.8 \%$ dissolved-N; $64.9 \% \mathrm{NH}_{3}-\mathrm{N} ; 33.8 \% \mathrm{NO}_{2}-\mathrm{N}$; $48.8 \% \mathrm{NO}_{3-}-\mathrm{N} ; 89.3 \%$ turbidity), while for the $S$. molesta, mean percentage removal efficiency was $72.1 \%$ total-P; $65 \%$ dissolved-P; $42.7 \%$ total-N; $36.4 \%$ dissolved-N; $60.9 \% \mathrm{NH}_{3}-\mathrm{N} ; 27.5 \% \mathrm{NO}_{2}-\mathrm{N}$; $83.8 \%$ turbidity. The control yielded the lowest mean percentage removal efficiency: $50.3 \%$ total-P; $34.3 \%$ dissolved-P; $22.8 \%$ total-N; $18.4 \%$ dissolved$\mathrm{N} ; 41.1 \% \mathrm{NH}_{3}-\mathrm{N} ; 21.1 \% \mathrm{NO}_{2}-\mathrm{N} ; 28.0 \% \mathrm{NO}_{3-}-\mathrm{N}$; $59.0 \%$ turbidity and the treatment with $S$. molesta showed the lowest removal of nitrate-N (1.2\%) (Figure 3).

\section{Aquatic macrophytes growth}

Figure 4 shows the dry mass of aquatic macrophytes for all the experimental period. The treatment with $E$. crassipes had a higher final biomass (1738.9 $\mathrm{g} \mathrm{DM} \mathrm{m}^{-2}$ ) than $P$. stratiotes $\left(665.3 \mathrm{~g} \mathrm{DM} \mathrm{m}^{-2}\right)$ and $S$. molesta (442.8 $\mathrm{g} \mathrm{DM} \mathrm{m}^{-2}$ ). Biomass values of $S$. molesta stabilised after 30 days.

\section{DISCUSSION}

There was an upward trend for the concentrations of phosphorus, nitrogen and turbidity in the pond fish effluent during the test period. These changes were probably associated with increasing feed supply, due to the fish body weight gain and decomposition of organic matter. At the end of the experiment the amount of feed added to the fish was three times higher than in the beginning, while Nile tilapia showed mean individual weight gain of $266 \mathrm{~g}$. Baccarin \& Camargo (2005) also observed positive correlations between fish body weight and the increases in the concentrations of total phosphorus, total nitrogen and suspended solids in the water.

The efficiency of both E. crassipes and $P$. stratiotes treatments in reducing turbidity probably was due to their great rhizosphere development and the shallowness of the tanks, which probably favoured the adsorption and precipitation of suspended particles. The treatment $S$. molesta presented a reduction on Nnitrate removal and intermediate removal values of the other nitrogen compounds, phosphorus and turbidity. The control had the lowest removal efficiency of turbidity and nutrients, with the exception of N-nitrate.

Although Reddy \& DeBusk (1985) concluded that $E$. crassipes is more capable of removing nitrogen and phosphorus than $P$. stratiotes, in the present work no significant differences were observed in the nutrient removal capacity of these two species. Other 

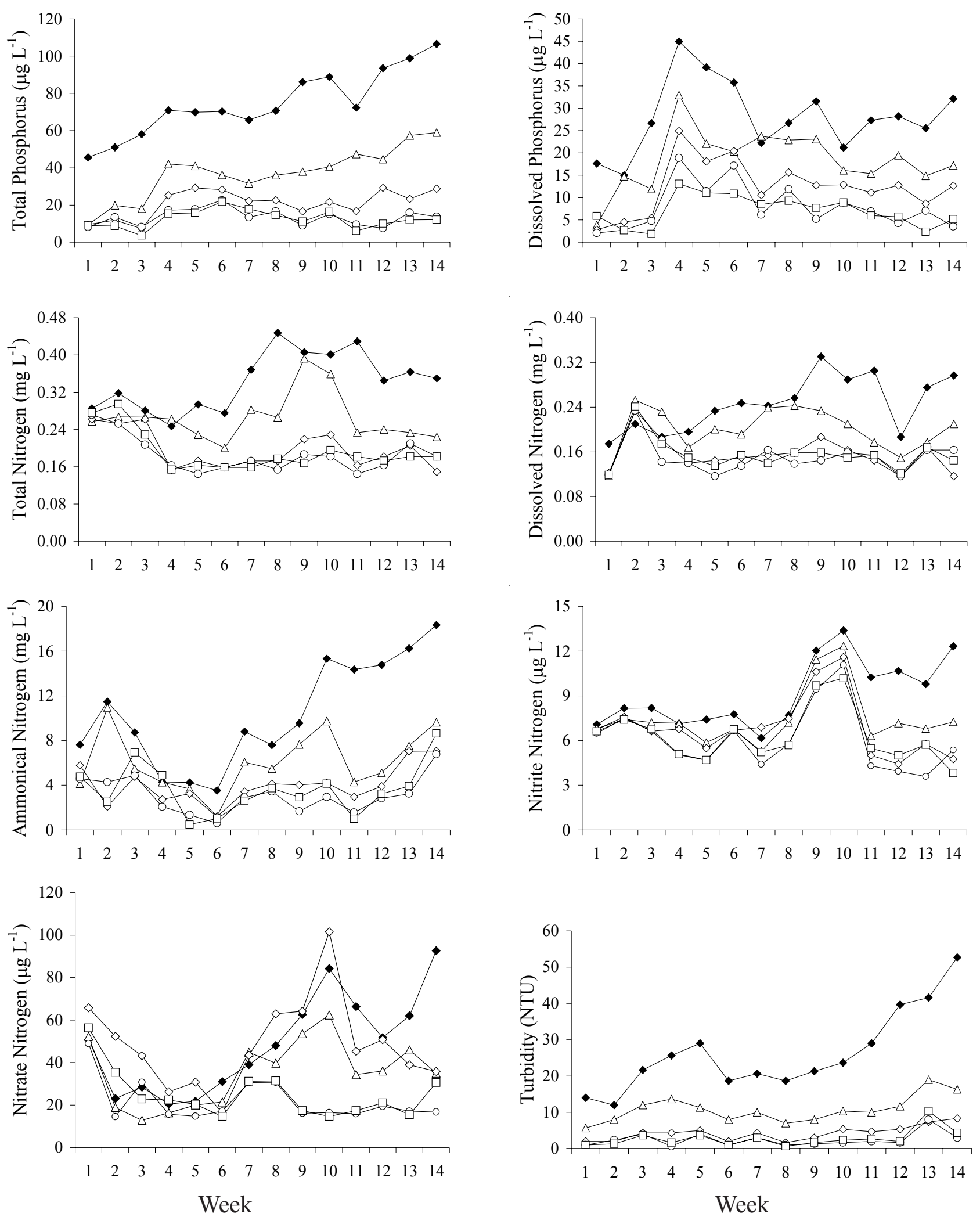

- Pond effluent $\triangle$ Control $\diamond$ S. molesta $\bigcirc$ E. crassipes $\square$ P. stratiotes

Figure 2 - Means of limnological parameters of pond effluent and treatments effluents by control, S. molesta, E. crassipes and P. stratiotes systems. NTU = Nepholometric Turbidity Units. 


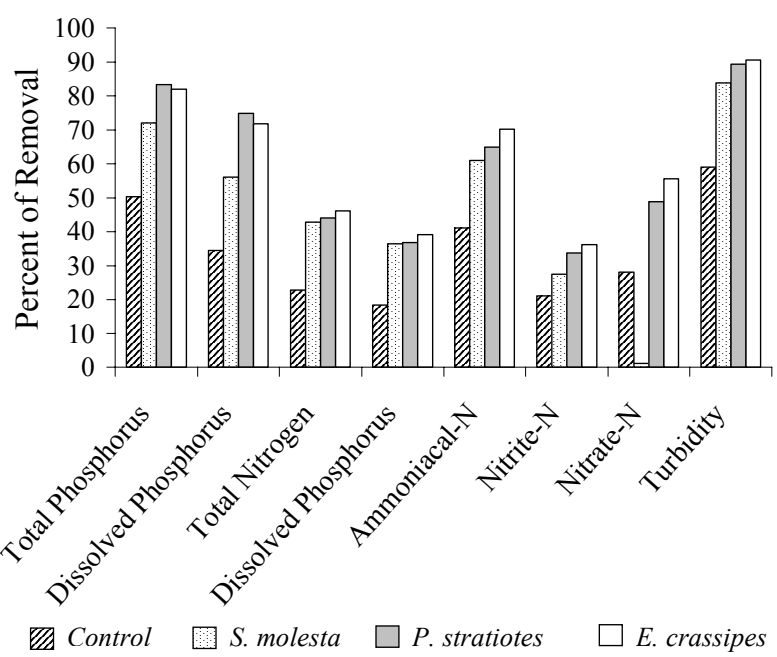

Figure 3 - Percent means (14 weeks) for removal of nutrients and turbidity by treatment systems.
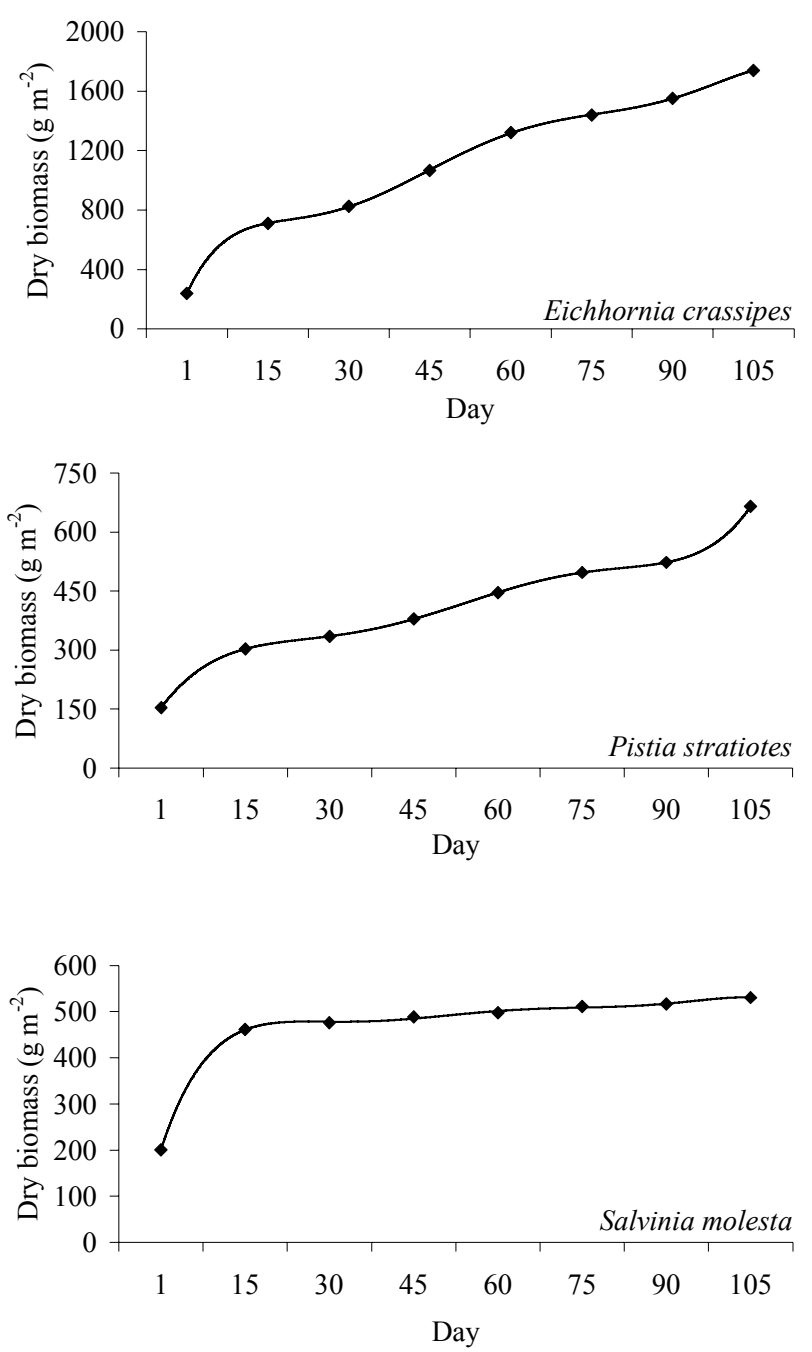

Figure 4 - Growth curves of free floating aquatic macrophytes along the experimental period. authors have observed that $E$. crassipes was less efficient in phosphorus removal than inorganic forms of nitrogen removal (Dunigan et al., 1975; Sooknah \& Wilkie, 2004). However all systems, including the treatment control, were more efficient in removing the total phosphorus content than the total nitrogen content.

Nutrient removal, mainly of phosphorus, was considerably higher than other systems used for the treatment effluents with high nitrogen and phosphorus concentrations. Manfrinato (1989) used E. crassipes to treat water from the Piracicaba River (from 0.10 to $0.27 \mathrm{mg} \mathrm{L}^{-1}$ of total-P and from 0.20 to $2.6 \mathrm{mg} \mathrm{L}^{-1}$ of ammoniacal-N) and reported $47 \%$ removal of total-P concentrations. DeBusk et al. (1983) used the same species to treat domestic effluents with high nutrient concentrations $\left(0.7 \mathrm{mg} \mathrm{L}^{-1}\right.$ of the $\mathrm{PO}_{4}^{3-}$ and $3.2 \mathrm{mg} \mathrm{L}^{-1}$ of the nitrate-N) and reported total phosphorus removal rates of $10 \%$. Redding et al. (1997), analysing macrophytes of different ecological groups to treat fish farm effluents, observed mean reductions of $4.3 \%$ for ammoniacal-N using Azolla filiculoides (floating), 8.2\% using Elodea nuttalli (submersed) and $10.7 \%$ using Roripa nasturtiumaquaticum (emergent).

The treatments E. crassipes and P. stratiotes presented similar efficiency for nutrient removal. However, E. crassipes weight gain was about 2.7 times higher than that of $P$. stratiotes. Considering the interest for using the biomass of aquatic macrophytes as plant compost, biogas production and animal feed, $E$. crassipes should be preferred as treatment for aquaculture effluents. On the other hand, if these goals are not of interest, $P$. stratiotes is recommended because of the lower gain of mass, thus reducing problems from exceeded biomass. In the present work, removal of plant biomass was not necessary due to the relatively short experimental period. It is recommended, however, that periodic cropping should be investigated as a means of maintaining high rates of vegetative growth in the macrophyte population and, consequently to create a positive effect on nutrient removal.

The potential absorption of nutrients by aquatic macrophytes is influenced both by biomass increase and by the concentration of nutrients in plant tissues. Therefore, species of aquatic macrophyte that have fast growth and capacity to produce higher biomass are more efficient for the treatment of aquaculture effluents. Probably because of the lower biomass of $S$. molesta this species was less efficient in the removal of nutrients than were E. crassipes and P. stratiotes. The biomass of $S$. molesta reached the maximum (carrying capacity) in the first month of the experiment, while the other two species increased biomass along four months. 
Quality of aquaculture effluents should not differ from the water quality used in the farms (Mires, 1995). E. crassipes and P. stratiotes presented higher efficiency in improving effluent quality because the effluent treated contained nitrogen and phosphorus at similar concentrations and, in some cases, lower nutrient concentrations in comparison to the inflow water of the Nile tilapia pond. Therefore, after macrophyte treatment, it is possible reusing effluent treated in fish farms and to release it into the aquatic ecosystem avoiding artificial eutrophication.

\section{ACKNOWLEDGEMENTS}

To Drs. Wagner Cotroni Valenti, Irineu Bianchini Jr. and Osmar Cantelmo for critical comments. Also to Dr. Neil Samuel Johnston for help in the English language. This research was supported by FAPESP and CEPTA-IBAMA.

\section{REFERENCES}

BACCARIN, A.E.; CAMARGO, A.F.M. Characterization and evaluation of the impact of feed management on the effluents of Nile tilapia (Oreochromis niloticus) culture. Brazilian Archives of Biology and Technology, v.48, p.81-90, 2005.

BOYD, C. Guidelines for aquaculture effluent management at the farm-level. Aquaculture, v.226, p.101-112, 2003.

COSTA-PIERCE, B.A. Preliminary investigation of an integrated aquaculture - wetland ecosystem using tertiary-treated municipal wastewater in Los Angeles County, California. Ecological Engineering, v.10, p.341-354, 1998.

DeBUSK, T.A.; WILLIAMS, C.; RYTHER, J.H. Removal of nitrogen and phosphorus from waste water in a water hyacinth - based treatment system. Journal of Environmental Quality, v.12, p.257-262, 1983.

DUNIGAN, E.P.; PHELAN, A.R.; SHAMSUDDIN, Z.H. The use of water hyacinths to remove nitrogen and phosphorus from eutrophication waters. Hyacinth Control Journal, v.13, p.5962, 1975

EL SAYED, A.F.M. Alternative dietary protein sources for farmed tilapia, Oreochromis spp. Aquaculture, v.179, p.149-168, 1999.

FARAHBAKHSHAZAD, N.; MORISON, G.M.; SALATI, E.F. Nutrient removal in a vertical upflow wetland in Piracicaba, Brazil. Ambio, v.29, p.74-77, 2000.

GOLTERMAN, H.L.; CLYNO, R.S.; OHSNTAD, M.A.M. Methods for chemical analysis of freshwater. Boston: Blackwell, 1978. 214p.

GREENWAY, M. The role of constructed wetlands in secondary effluent treatment and water reuse in subtropical and arid Australia. Ecological Engineering, v.25, p.501-509, 2005.

HADAD, H.R.; MAINE, M.A.; BONETTO, C.A. Macrophyte growth in a pilot-scale constructed wetland for industrial wastewater treatment. Chemosphere, v.63, p.1744-1753, 2006.
HENRY-SILVA, G.G.; CAMARGO, A.F.M. Avaliação sazonal da biomassa da macrófita aquática Eichhornia azurea em um rio de águas brancas da bacia hidrográfica do rio Itanhaém (litoral sul do estado de São Paulo, Brasil). Hoehnea, v.30, p.71-77, 2003.

HENRY-SILVA, G.G.; CAMARGO, A.F.M. Interações ecológicas entre as macrófitas aquáticas flutuantes Eichhornia crassipes e Pistia stratiotes. Hoehnea, v.32, p.445-452, 2005.

KOROLEFF, F. Determination of nutrients. In: GRASSHOF, K, (Ed.) Methods of seawater analysis. Weineim: Verlag Chemie, 1976. p.117-181.

LIN, Y.F.; JING, S.R.; LEE, D.Y.; CHANG, Y.F.; CHEN, Y.M.; SHIH, K.C. Performance of a constructed wetland treating intensive shrimp aquaculture wastewater under high hydraulic loading rate. Aquaculture, v.134, p.411-421, 2005.

MACKERETH, F.I.F.; HERON, J.; TALLING, J.F. Water analysis: Some revised methods for limnologist. London: Freshwater Biological Association, 1978. 121p.

MANFRINATO, E.S. Avaliação do método edafo-fitodepuração para tratamento preliminar de águas. Piracicaba: USP/ESALQ, 1989. 98p. (Dissertação - Mestrado).

MIRES, D. Aquaculture and the aquatic environment: mutual impact and preventive management. The Israeli Journal of Aquaculture, v.47, p.163-172, 1995.

PIEDRAHITA, R.H. Reducing the potential environmental impact of thank aquaculture effluents through intensification and recirculation. Aquaculture, v.226, p.35-44, 2003.

RAN, N.; AGAMI, M.; ORON, G. A pilot study of constructed wetlands using duckweed (Lemna gibba L.) for treatment of domestic primary effluent in Israel. Water Research, v.38, p.2241-2248, 2004.

REDDING, T.; TODD, S.; MIDLEN, A. The treatment of aquaculture wastewater - A botanical approach. Journal of Environmental Management, v.50, p.283-299, 1997.

REDDY, K.R.; DeBUSK, W.F. Nutrient removal potential of selected aquatic macrophytes. Journal of Environmental Quality, v.14, p.459-462, 1985.

SINGHAL, V.; RAI, J.P.N. Biogas production from water hyacinth and channel grass used for phytoremediation of industrial effluents. Bioresourse Technology, v.86, p.221-225, 2003.

SOOKNAH, R.D.; WILKIE, A.C. Nutrient removal by floating aquatic macrophytes cultured in anaerobically digested flushed dairy manure wastewater. Ecological Engineering, v.22, p.2742, 2004.

STEPHENS, W.; FARRIS, J.L. A biomonitoring approach to aquaculture effluent characterization in channel catfish fingerling production. Aquaculture, v.241, p.319-330, 2004.

THOMAZ, K.J.; BINI, L.M. Ecologia e manejo de macrófitas aquáticas em reservatórios. Acta Limnológica Brasiliensia, v.10, p.103-116, 1998.

TRUE, B.; JOHNSON, W.; CHEN, S. Reducing phosphorus discharge flow through aquaculture I: facility and effluent characterization. Aquacultural Engineering, v.32, p.129-144, 2004.

ZAR, J.H. Biostatistical analysis. 4.ed. New Jersey: Prentice Hall, 1999. 380p.

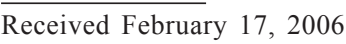

Accepted July 04, 2006 